\title{
AS SOCIEDADES CONTRA O ESTADO EXISTEM? RECIPROCIDADE E PODER EM PIERRE CLASTRES ${ }^{*}$
}

Marcos Lanna

Para Tomas Teixeira Pinto

"It may be devil, it may be the Lord, you're gonna have to serve somebody" Bob Dylan

Em "As organizações dualistas existem?", de 1956, Claude Lévi-Strauss (1958) retoma a seguinte questão: "como podem ser hierarquizadas metades presas a obrigações recíprocas e exercendo direitos simétricos?" (Lévi-Strauss 1958:155; cf. tb. Lévi-Strauss 1944). Sua resposta demonstra que:

a) o dualismo simétrico e diametral pode ser uma expressão do dualismo assimétrico e concêntrico;

b) podemos "tratar como sistemas ternários" algumas "formas de organização social habitualmente descritas como binárias" (Lévi-Strauss 1958: 171); e

c) que "todo esforço para passar da tríade assimétrica à díade simétrica supõe o dualismo concêntrico", simultaneamente diádico e assimétrico (Lévi-Strauss 1958:168).

Ligado a esta tripla demonstração, situa-se o fato, menos discutido, de que Lévi-Strauss elabora ali, sem conclusão expressa, as seguintes possibilidades:

1. de que a "troca restrita" e simétrica, como a exemplificada pelos casamentos com a prima cruzada bilateral, possa ser não a origem (lógica e histórica), mas sim a regressão da "troca generalizada" e assimétrica, como a exemplificada pelo casamento matrilateral. Lévi-Strauss assume que "do ponto lógico seria simultaneamente mais razoável e mais econômico tratar a troca restrita como um caso particular da troca generalizada" (1958:167) e dá algumas sugestões para um tratamento empírico desta questão, salientando que tais questões só poderiam ser aprofundadas após mais análises etnográficas; 
2. de que "talvez em todas" (ênfase minha) as "organizações dualistas" houvesse uma combinação destes "três tipos de representações: dualismo diametral, dualismo concêntrico e tríade" (Lévi-Strauss 1958:166). Os dualismos concêntrico e diametral seriam certamente "duas maneiras de descrever uma organização" (Lévi-Strauss 1958:149), mas seria esta organização passível de ser representada por uma tríade universal? Seriam os dois dualismos perspectivas de um universal assimétrico? Quanto a este ponto, Lévi-Strauss oscila: ora assume haver distinção entre simetria "falsa" (concêntrica e triádica) e "verdadeira" (diametral e diádica), ora toma as diversas formas da segunda como "tríades disfarçadas de díades graças ao subterfúgio lógico que consiste em tratar como dois termos homólogos um conjunto realmente formado de um pólo e um eixo, que não são objetos da mesma natureza" (Lévi-Strauss 1958:170).

Ainda quanto a isto, Lévi-Strauss inicia o texto de modo cauteloso: "não nos escapa que os elementos de uma estrutura diametral também possam ser desiguais. Este é, sem dúvida, o caso mais freqüente, visto que encontramos em suas denominações [nas metades Ge e Bororo, por exemplo] expressões como: superior e inferior, mais velho e mais novo, nobre e plebeu, forte e fraco etc. Mas para as estruturas diametrais esta desigualdade nem sempre existe e de qualquer modo não decorre de sua natureza, que está impregnada de reciprocidade" (Lévi-Strauss 1958:154-55). No decorrer do artigo, entretanto, não dá exemplo algum dos casos supostamente existentes, mas "menos freqüentes", onde a simetria seria "real" e a desigualdade inexistente. Ao contrário, o que faz é mostrar a generalidade da tríade.

O que farei aqui será refletir sobre esta questão da universalidade da assimetria a partir da obra de Pierre Clastres, ou de partes dela, e do reconhecimento de que não é apenas a estrutura diádica que está "impregnada de reciprocidade". Esta questão perturbava tanto Clastres como Lévi-Strauss. Veremos que o primeiro parece partir das preocupações do segundo para posteriormente oferecer a ela um tratamento particular. Por isto, a obra de Clastres permite-nos a passagem de uma assimetria abstrata e referida à troca para a questão propriamente dita do poder e do Estado. Não irei, assim, seguir aqui a sugestão de Lévi-Strauss de dar um tratamento empírico a esta questão, mas por outro lado seguirei sua perspectiva teórica, retomando um diálogo entre sua obra e a de Pierre Clastres que, afinal de contas, foi proposto por este último. Ficará ainda implícito que este diálogo poderia e deveria ser aprofundado em outros trabalhos a partir de uma perspectiva mais etnográfica que recuperasse a constituição de uma esfera da política ou do poder ou da 
chefia em diferentes províncias etnográficas, sejam elas das terras baixas sul-americanas ou não.

Por introduzir questões fundamentais, a "antropologia política" de Pierre Clastres tem sido amplamente debatida há décadas. Alguns comentadores apontam uma descontinuidade entre as coletâneas $A$ sociedade contra $o$ Estado, de 1974, e Arqueologia da violência, de 1980, pois na primeira "o signo irredutível da diferença é a ausência de Estado", enquanto na segunda também a guerra aparece "como fundamento da sociedade primitiva" (Fausto 1999:257-259). Nesta obra posterior, "Clastres debate com a antropologia de Lévi-Strauss, refutando a idéia da troca como fundamento único do social" (Cohn e Sztutman 2003:A46; cf. tb. Fausto 1999:259). Em relação à coletânea de 1974, a de 1980 caracterizaria uma maior rebeldia em relação a LéviStrauss; este passa a ser alvo de críticas mais explícitas, particularmente quanto à idéia de uma passagem da guerra à troca, supostamente por ele entendida como tendência histórica necessária.

Haveria, entretanto, críticas já na primeira obra:

Recusando o modelo jurídico da política e do Estado, Clastres focalizou a chefia, buscando, a um só tempo, problematizar o modelo da reciprocidade em sua capacidade de dar conta por si só da sociedade primitiva, e aprender a filosofia política particular que ela exprime [...] Contestando as conclusões de Lévi-Strauss em sua breve reflexão sobre a chefia Nambikwara, Clastres demonstrou que a relação da sociedade indígena com a instituição política não poderia ser reduzida à reciprocidade. Bem ao contrário, essa instituição destaca-se muito mais como um nódulo que desvia mulheres, bens e palavras de sua função de comunicação, uma vez que a via que cada um destes termos percorre, entre o chefe e o grupo, é unidirecionada (Lima e Goldman 2003:14).

As críticas do livro de 1974, entretanto, são implícitas e acompanhadas por uma série de menções elogiosas ao mestre. Sem deixar de notar as descontinuidades, veremos que há também outras importantes continuidades entre $A$ sociedade contra o Estado e Arqueologia da violência. Lima e Goldman apontam aquela que seria, a meu ver, fundamental: a proposição de um modelo para a chefia indígena. Este modelo do chefe "prisioneiro do grupo" (Clastres 2003a:63) é também o da "sociedade" ${ }^{1}$ credora do chefe. Outra continuidade, ou talvez outro aspecto daquele 
modelo, seria uma definição do "Estado" a partir de uma inversão em relação à figura do chefe, esta passando de prisioneira/devedora a credora da "sociedade". Ora, tais continuidades não são duas, mas uma: a definição tanto do "Estado" como da chefia primitiva a partir da dívida. Em um caso, há dívida do chefe em relação à "sociedade" — é ela que permite o aprisionamento do primeiro - no outro, é o Estado que se torna credor. Este segundo caso é mais explicitamente elaborado por Clastres em termos de "dívida". Para haver submissão ao "Estado" e trabalho para outrem "a regra de troca é substituída pelo terror da dívida" (Clastres 2003a:215), uma dívida específica, da sociedade em relação ao "poder".

Esta definição lógica do "Estado" ganha fundamento histórico na interpretação de vários autores. Para além dos americanistas, que Clastres tanto influenciou, poderíamos citar Luc de Heusch, que propõe ser a figura das realezas sagradas (todas elas e não apenas as suas institucionalizações africanas) "germe mediador entre estes dois termos [a sociedade 'arcaica' e o Estado]" (de Heusch 1987:56). De Heusch assume a tese da inversão da dívida, mas supõe que o surgimento do Estado na história seria necessariamente precedido da "emergência de uma instituição mágico-religiosa específica como laço exterior ao parentesco e capaz de quebrar o controle que este exerce sobre o todo das relações sociais" (1987:56).

Sem entrarmos no mérito da tese - discutível inclusive por generalizar uma precedência do parentesco que é dubitável mesmo em ambiente linhageiro africano - não devemos estranhar a perspectiva evolucionista de de Heusch (1987:55), da qual este autor não parece consciente, chegando a negá-la explicitamente. Afinal, apesar da interpretação que lhe dá Clastres, o modelo da "sociedade contra o Estado" não exclui, nele mesmo, necessariamente, a idéia evolucionista de sociedade "pré-estatal", ou por outra, este modelo pode ser entendido - assim parece fazer de Heusch - como propondo uma substituição do "pré-estatal" pelo "contra-estatal". A divergência aqui é entre a ruptura qualitativa apresentada por Clastres e uma evolução gradativa, tipicamente suposta no século XIX e posteriormente recolocada, ainda que de modo sofisticado, por de Heusch. A rápida menção a fatos africanos, que aparecerá mais adiante neste artigo, justifica-se tanto pelos propósitos generalistas de Clastres - afinal, é de uma definição do Estado que se trata aqui - como, mais importante, pela possibilidade de interpretarmos a análise de de Heusch não em termos de rupturas qualitativas nem de transformações históricas, mas sim a partir de transformações lógicas da figura da chefia, entendida como uma posição assimétrica, mais ou menos centralizadora ou concêntrica em cada caso. 
O argumento central deste artigo será assim no sentido de recuperar a definição do Estado de Clastres e, ao mesmo tempo, criticar seu modelo da chefia, ou melhor, criticar a idéia de que a ausência de uma força como potência de sujeição e com capacidade de coerção definiria a natureza das sociedades primitivas como "contra o Estado". Refletirei ainda sobre o fato de que se o chefe primitivo de Clastres está em dívida com a sociedade, isto significa que este autor não só "problematiza" (Lima e Goldman 2003) ou "vai de encontro" (Fausto 1999:257) "ao modelo da reciprocidade", mas também o reelabora. Isto é, há em Clastres críticas ao modelo da reciprocidade, mas isto não exclui o fato - mais importante, talvez - de usá-lo. Ele o utiliza duplamente: de modo consciente, reduzindo-o, ao afastá-lo da noção de dívida; e de modo inconsciente, ele o expande, ao pensar o político, tanto a chefia primitiva como o Estado, a partir da dívida. Deixaremos de ver como exclusivas as hipóteses de Clastres criticar ou reelaborar o princípio de reciprocidade se analisarmos detidamente sua compreensão deste princípio.

Como então Clastres simultaneamente critica e utiliza o princípio de reciprocidade de Lévi-Strauss? Paradoxalmente, Clastres o reduz, por afastá-lo da assimetria da dívida, mas também o expande, ao renovar a idéia de utilizá-lo para a construção de uma antropologia política. Esta idéia foi inicialmente apresentada na década de 1940 na análise de Lévi-Strauss da chefia Nambikwara, mas já se esboçara anos antes na sua descrição do chefe Bororo, aliás, visto não como fraco ou figura englobada, ao modo de Clastres, mas impositor da "disciplina da população", capaz de dar ordens, comandar trabalho alheio, "presidir a vida econômica da tribo", portador de "poderes vastos", de "grande autoridade [...] não vimos jamais uma ordem sua não ser escrupulosamente executada", ainda que "os indígenas não se privassem de se lançar contra ele", ironizassem "sua preguiça e seu hábito de fazer seus subordinados trabalharem para seu benefício próprio" (Lévi-Strauss 1936:283) ${ }^{2}$. Veremos a seguir como Clastres obscurece a impressão da figura particular de um chefe portador de poder, cunhando uma figura inversa desta e geral, pois não apenas ameríndia, do chefe prisioneiro do grupo.

Há assim, em A sociedade contra o Estado, uma tentativa de retomar e de transformar um modelo reconhecidamente bem-sucedido - pelo próprio Clastres - na análise do parentesco, utilizando-o para pensar o político. Em entrevista de 1974 (Clastres 2003b) e em trechos de Arqueologia da violência, Clastres reverencia Lévi-Strauss como o grande mestre dos estudos do parentesco e da mitologia. Uma conclusão possível feita, a meu ver, por Clastres - mais ou menos conscientemente - no início da década 
de 1960 foi a de que restaria levar o estruturalismo à política. Naquela altura, como lembrei, as referências de Clastres a Lévi-Strauss eram sempre elogiosas. O estruturalismo de Lévi-Strauss evidencia-se nos textos da década de 1960 na medida em que, neles, Clastres busca superar concepções puramente instrumentais da política, da mesma forma que Lévi-Strauss já tentara fazê-lo nas suas reflexões sobre os Nambikwara: "pode-se dizer que a liderança não existe como um resultado das necessidades do bando mas, ao invés, que o bando recebe sua forma, seu tamanho e mesmo sua origem do líder potencial que o precede" (LéviStrauss apud Dal Poz 2004:157; cf. tb. Lévi-Strauss 1996:291). Esta idéia de um chefe com capacidade para "gerar um todo" é evidentemente próxima da noção de hierarquia de Louis Dumont.

Outra conclusão possível - como a que foi feita por Clastres no início da década de 1970 - a partir do reconhecimento de Lévi-Strauss como mestre dos estudos dos mitos e das estruturas elementares do parentesco, seria a de que o estruturalismo se reduz a estes temas e a este autor. Nessa época, Clastres já desistira de uma análise estruturalista da política, como Lévi-Strauss décadas antes, mas certamente por outros motivos, quiçá opostos (ou seja, a busca de uma antropologia mais e não menos engajada), que cabem a futuros estudos da história da antropologia francesa desvendar. Entre outras razões, Clastres, corretamente a meu ver, argumenta no sentido de a análise da política não prescindir da sociologia; "o que Clastres reprova no estruturalismo é ter, ao concentrar sua atenção nos mitos e nas estruturas de parentesco, omitido a questão da sociedade" (Abensour 1987:9). Sem ter espaço para aprofundar esta questão, deixarei implícito que não me parece que Lévi-Strauss, por sua vez, tenha realmente omitido "a questão da sociedade".

A trajetória de Clastres pode ser assim descrita: inicialmente, dá uma contribuição vital ao retomar a construção de uma antropologia política estruturalista, tarefa abortada por Lévi-Strauss no início dos anos 1940; posteriormente, abandona o estruturalismo para - e aqui me sinto obrigado a usar uma metáfora já abusada - jogar fora o bebê com a água do banho, ou seja, em nome de retomar considerações sociológicas, cair, como veremos, em uma postura funcionalista, cuja crítica já havia sido feita de modo definitivo por Lévi-Strauss, ainda que não devidamente absorvida até hoje pela antropologia em geral (cf. Sahlins 2004, para indicações brilhantes de como a crítica ao estruturalismo pode facilmente significar um retorno ao funcionalismo e, no caso de algumas tendências recentes da antropologia, a uma redução da vida social ao poder). Mais ainda, como nota Abensour (1987:9), Clastres deixa implícita a crítica de 
que o estruturalismo não teria entendido a "sociedade primitiva como forma específica de instituição social". Tentarei aqui mostrar, ao contrário, que o modelo de "sociedade contra o Estado" de Clastres constrói uma especificidade primitiva, mas vendo-a lá onde ela não está.

Como vimos, um dos modos em que o princípio da reciprocidade se faz presente na definição de Clastres do político é através da noção de dívida (neste caso, tanto seu entendimento do chefe primitivo como da figura do "Estado"). A interpretação consciente de Clastres daquele princípio, por sua vez, restringe-o à sua noção de "troca recíproca" ou "regra igualitária de troca" (Clastres 2003a:215), uma noção que implica simetria, equivalência e igualdade, jamais assimetria, inequivalência e desigualdade. Uma interpretação muito particular do princípio de reciprocidade, tal como apresentado por Lévi-Strauss em As estruturas elementares do parentesco, aparece também na noção de Clastres de "sociedade" como derivada desta "troca recíproca". Poderíamos pensar aqui em "sociedade" como um termo geral, não restrito às sociedades indígenas ou "contra o Estado". Seria esta "sociedade" geral ora credora do chefe, ora devedora do "Estado"?

Aparentemente não para Clastres. Apesar de este preferir não ver diferenças essenciais entre as sociedades indígenas e as outras, uma fórmula já citada (o "Estado" implica que "a regra de troca" seja "substituída pelo terror da dívida") sugere que para ele a regra da troca recíproca constituiria apenas as primeiras, enquanto a dívida constituiria as sociedades com "Estado". Assim, a dívida que o chefe primitivo, prisioneiro do grupo, teria com a sociedade primitiva não constituiria esta última. Mas se aceitarmos relacionar o princípio de reciprocidade não apenas à troca, mas também à dívida - qualquer movimento unidirecionado de pessoas ou bens materiais e imateriais já constituindo uma dádiva, e toda dádiva se definindo pela dívida, mais do que pela retribuição efetiva ou por uma contraprestação equivalente - o termo "sociedade" ganha estatuto geral. O termo "Estado" também o ganharia se definido como centralizador de prestações, com a capacidade de redistribuir e a prerrogativa de tributar. Poderíamos assim vir a argumentar futuramente que o chefe primitivo seria uma variante da figura do Estado e que este está presente na sociedade primitiva, ainda que sem o seu poder coercitivo. A meu ver, era este o entendimento de Lévi-Strauss da chefia Nambikwara, "o con- 
sentimento" não seria fundamento, mas "dimensão psicológica" deste "poder não-coercitivo". O casamento poligâmico seria "condição técnica do poder" e "a noção de reciprocidade outro atributo fundamental do poder". Esta chefia não estaria tão distante de uma "concepção do Estado como um sistema de garantias", que seria "como um regime nacional de previdências" e "não um fenômeno puramente moderno. É um retorno à natureza fundamental da organização social e política" (Lévi-Strauss 1996:298).

Mas o que importa aqui é o desenvolvimento que Clastres dá a esta sugestão de articular troca e chefia. Para este autor, a ausência do poder coercitivo seria a prova de que a sociedade primitiva seria bem-sucedida em sua empreitada "contra o Estado", a "sociedade contra o Estado" sendo "sociedade com poder não-coercitivo" (Abensour 1987:16). Assim, se em A sociedade contra o Estado a sociedade primitiva define-se ontologicamente pela troca recíproca e igualitária, ela não deixa de se definir também topologicamente por uma posição credora em relação ao chefe, por sua capacidade para exteriorizar este último. Clastres supõe que "a natureza da sociedade muda com o sentido da dívida" (Clastres 1976:26); as primitivas "impõem uma dívida permanente ao líder para impedi-lo de transformar seu prestígio em poder" (de Heusch 1987:41; meu grifo enfatiza a razão prática deste autor, um entendimento da dívida como mero instrumento ou meio para obtenção de determinados objetivos ou fins da "sociedade primitiva"). O estatuto da sociedade indígena seria, para Clastres, essencialmente diferente daquele das "com Estado", em função de as primeiras se caracterizarem pela troca e as segundas pela dívida; entretanto, ambas se definem também em relação ao Estado, ora recusando-o, ora deixando-se definir e submeter por este. O argumento implica ainda um nível psicológico: a radical recusa do "Estado" requereria certa sagacidade ${ }^{3}$.

Clastres deixa explícito que, no caso primitivo, a "sociedade" deriva da troca, ou melhor, de uma interpretação do modelo da reciprocidade de Lévi-Strauss muito em voga nos anos 1960 (cf. Lanna 1996), tomando a troca como "regra igualitária" (Clastres 2003a:215). Ora, esta interpretação confunde a simetria da perspectiva dos trocadores de primas cruzadas implícita na noção de troca das Estruturas elementares do parentesco (cf. Dal Poz 2004), com equivalência ou simetria na posição social dos trocadores ou da valoração daquilo que é trocado (para a distinção entre simetria e equivalência, cf. tb. Dal Poz 2004:39), quando "não há porque adstringir a noção de reciprocidade apenas às relações em que se postula uma igual valência entre o que se troca ou uma 
posição simétrica a quem troca" (Dal Poz 2004:156). Ora, o modelo lévistraussiano não pode ser reduzido à equivalência nem à simetria (e talvez mesmo Dal Poz tenha enfatizado desnecessariamente a demanda da simetria na perspectiva dos trocadores de primas cruzadas, mas isto já seria assunto para outra ocasião).

Como afirma Fausto, "para Clastres, a lógica do dom é uma lógica da identidade, enquanto a lógica da guerra é uma lógica da diferença, de recusa da identificação do um ao outro" (Fausto 1999:260). Mas as reflexões de Lévi-Strauss (1949) sobre a troca generalizada evidenciam uma compreensão do dom como articulador lógico de identidades e diferenças, assim como o artigo "Guerra e comércio entre os índios da América do Sul" mostra que Lévi-Strauss (1976[1942]) não exclui a presença na guerra de uma lógica da identidade, muito pelo contrário. A meu ver, é a partir desta ótica que devemos compreender o fato de que o princípio de reciprocidade "tem o valor de verdadeiro princípio transcendental no estruturalismo, isto é, ele enuncia uma condição geral e a priori de toda experiência humana, inclusive da guerra" (Fausto 1999:260).

Mas isto não é tudo. Se o princípio lévi-straussiano da reciprocidade aparece inconscientemente na definição do "Estado" de Clastres (logicamente através da dívida e institucionalmente como figura capaz de tributar), e conscientemente na de "sociedade" (neste caso, não o princípio exatamente, mas uma interpretação particular que o aproxima excessivamente da igualdade e da simetria), ele surge ainda uma vez em outro momento decisivo de sua obra, na organização da "esfera política como exterior à estrutura do grupo" tornando impotente "a região do poder" (Clastres 2003a:63); isto porque tanto esta "esfera política" primitiva quanto a "sociedade" (ou, sempre nas palavras de Clastres, "a estrutura do grupo") definem-se, diferentemente em cada caso, como universos de circulação de bens, mulheres e palavras. No primeiro caso, da "esfera política", esta circulação é uma "não-troca", ou melhor, para usar termo de Clastres que revela influência marxista, uma "troca aparente": "por referência imediata a estes três tipos de sinais se constitui a esfera política" (Clastres 2003a:55). Já no segundo caso, "a sociedade" se constituiria, como vimos, por uma troca igualitária. Em Clastres, o princípio de reciprocidade determinaria a constituição do termo "sociedade", mas não "a relação entre poder e sociedade" (Clastres 2003a:55, ênfase minha). Esta se caracterizaria pelos fluxos supostamente unidirecionados (e por isto por ele entendidos como "não-troca") de bens e palavras da "região do poder" para a "sociedade", e de mulheres da "sociedade" para aquela: 
[...] uma relação original entre a região do poder e a essência do grupo se desvenda então aqui: o poder mantém uma relação privilegiada com os elementos cujo movimento recíproco funda a própria estrutura da sociedade; mas esta relação, negando-lhes um valor que é de troca no nível do grupo, instaura a esfera política não apenas como exterior à estrutura do grupo, mas bem mais como negando esta: o poder é contra o grupo e a recusa da reciprocidade como dimensão ontológica da sociedade é a recusa da própria sociedade (Clastres 2003a:59).

Há aqui reconhecimento de que "a essência do grupo" é dada pela reciprocidade; esta reciprocidade é, entretanto, recusada pelo grupo em sua relação com o poder, recusa recíproca, aliás, que funda uma exterioridade. Mas para aceitarmos a tese da exterioridade, temos que aceitar a presença do poder na sociedade primitiva, mesmo que seja um poder não-coercitivo (ou, eu preferiria, englobado) - dada a suposição de Clastres de que as sociedades primitivas se caracterizariam pela ausência de um poder político no sentido de uma força, potência de sujeição e capacidade de coerção. A tese é a de que a "sociedade" recusa o poder e este recusa o "grupo" ao aceitarem (ambos os termos) a relação de (uma imaginada) "não-troca" de bens, mulheres e palavras, o "poder" aceitando assim que "a reciprocidade como dimensão ontológica da sociedade [...] é a própria sociedade". A recusa de Clastres é a de que o poder se fundamente na reciprocidade; poder e reciprocidade seriam para ele excludentes: "a relação do poder com a troca" seria "negativa" (Clastres 2003a:60) e o princípio de reciprocidade não "articula sociedade com seu poder" (Clastres 2003a:56).

Lima e Goldman (2003:14) colocam a questão em termos exatos: "o modelo da reciprocidade" para Clastres (leia-se então, nos termos deste, da "regra igualitária da troca") não "daria conta por si só da sociedade primitiva", em especial de "aprender a filosofia política particular que ela exprime". Mas teria mesmo Clastres "demonstrado que a relação da sociedade indígena com a instituição política não poderia ser reduzida à reciprocidade"? Como vimos, suas definições da chefia primitiva e do Estado pressupõem ou podem ser interpretadas em termos do "modelo da reciprocidade" quando, ao contrário do que faz Clastres, deixamos de reduzir este modelo às trocas igualitárias e entendemos a dívida como um dos modos de manifestação institucional (e quiçá até mesmo lógico) da reciprocidade e referimos o princípio de reciprocidade não à troca, mas à circulação assimétrica.

Bem resumido por Lima e Goldman (2003:14), o argumento de Clastres é o de que a "instituição política" primitiva "destaca-se muito 
mais como um nódulo que desvia mulheres, bens e palavras de sua função de comunicação, uma vez que a via que cada um destes termos percorre, entre o chefe e o grupo, é unidirecionada. Note-se que "a instituição política primitiva" se expressa, neste momento do argumento, mais no termo da chefia do que na relação entre ela e a "sociedade"; note-se ainda que não estamos falando da "instituição política" em geral, mas sim da "primitiva". Ora, seria mesmo tal via unidirecionada, como quer Clastres? E caso positivo, um circuito unidirecionado ou unilateral qualquer excluiria a reciprocidade? Clastres deriva sua conclusão de unidirecionalidade do fato, demonstrado por inúmeras etnografias, de que o chefe tem o "privilégio" da poliginia (de novo, o termo "privilégio" é de Clastres 2003a:53;56), mas esta já havia aparecido em uma análise inicial de Lévi-Strauss da chefia Nambikwara, como "privilégio do chefe" (LéviStrauss 1943:399); na análise da chefia Bororo, Lévi-Strauss fala em "privilégios sociais" (1936:278) ou "de clãs" (1936:287, como adornos e objetos) e o "dever" da generosidade e da oração, da palavra. Clastres generaliza assim, não sem boa base etnográfica a respeito de outros continentes, fatos ameríndios para uma teoria da "sociedade contra o Estado" ou, até mesmo como sugiro aqui, desta figura em sua relação com o "Estado". Insiste em que não está propondo uma troca de mulheres por bens e palavras, mas sim uma não-troca, tripla por sinal, de bens, mulheres e palavras, ou ainda como vimos, uma "relação aparentemente de troca" (Clastres 2003a:54).

Gostaria de salientar que Clastres dá uma contribuição fundamental tanto em sua ambição generalizadora como, talvez mais importante, ao especificar a existência do que denomina "circuitos próprios", de bens, mulheres e palavras. O que me parece criticável é a idéia de que a presença da unidirecionalidade implique ausência de reciprocidade. Minha sugestão, já mencionada, desenvolvida alhures (Lanna 1992, 1994, 1995, 1996), é a de substituir a noção de troca pela de circulação de dívidasdádivas: importa exatamente a reciprocidade gerada pela unidirecionalidade, por um movimento unilateral, que sempre se acompanha por movimentos em sentido contrário, ou em sentidos diversos (além de outros no mesmo sentido do inicial). Assim, por exemplo, a gratidão é um sentimento gerado por uma prestação e que em si mesmo já configura reciprocidade; ela pode ou não dar origem a uma contraprestação e esta pode ou não ser material, implicar o recebimento de algo (pessoa, palavra, bem material ou imaterial ou sinal, como um gesto).

Em um certo sentido, toda circulação é unidirecionada e todas as prestações e contraprestações, ainda que possam ser mais ou menos ime- 
diatas, fundam movimentos também unidirecionais, em sentido inverso. Um movimento de um objeto " $\mathrm{x}$ " em um sentido pode ser contrabalançado de modo mais imediato por um movimento de um objeto semelhante, mais ou menos idêntico, no sentido contrário e seria contrabalançado de modo menos imediato por oferecimentos de objetos de tipo diverso; em ambos os casos, é de reciprocidade que se trata. Nas estruturas elementares do parentesco, por exemplo, haveria menos unidirecionalidade na troca restrita do que na generalizada-patrilateral. A unidirecionalidade não exclui a comunicação; ao contrário, esta a pressupõe.

Não poderíamos assim confundir tal característica da circulação, de toda circulação, através de circuitos unidirecionados, com o obscurecimento, da parte de Clastres, do fato de que o chefe não só recebe mulheres, mas também as dá, da mesma forma que não só dá palavras e bens, mas também os recebe. Assim o fazendo, Clastres obscurece aquilo que ele mesmo tão bem denominou "circuitos próprios". Estes, segundo a própria definição da dádiva de Mauss, podem ser unidirecionados, mas não sem reciprocidade. Obscurece-se também a continuidade entre chefia e Estado, pois se este tem a prerrogativa de receber tributos, a primeira não deixa de receber bens. Bastaria investigarmos, em um caso particular qualquer, com quem casam as filhas e as irmãs do chefe para identificarmos, se não exatamente troca - pois esta relação não é necessariamente de troca, mas de dívida - circulação de mulheres. Teríamos um "circuito próprio" no sentido de que as mulheres não seriam exatamente trocadas, ou só o seriam, ou só poderiam ser concebidas assim, por ideologias de grupos particulares. Ainda aqui há influência em Clastres da análise de Lévi-Strauss da chefia Nambikwara. Para Lévi-Strauss (1943:400), o chefe "retira várias das mais jovens e bonitas mulheres do ciclo regular de casamentos". Isto sugeriria excepcionalidade nos casamentos dos chefes, como se este circuito contrastasse com aquele "regular" e como se não estivessem ambos em relação, ou melhor, como se ambos não fossem circuitos regulares, assimétricos e desequilibrados, mas não sem reciprocidade.

Não podemos ainda entender a expressão "unidirecionalidade" como se cada um destes circuitos fosse completamente autônomo dos demais. Isto é, a reciprocidade está tanto nas relações entre as prestações como naquelas entre os circuitos. As mulheres, por exemplo, estariam sempre em relação recíproca entre elas, isto é, entre as que vão para o chefe e as que vêm dele; é neste sentido que a reciprocidade (transcendente) dissolve a "unidirecionalidade" (institucional); poderíamos assim pensar em relações recíprocas entre os próprios circuitos — cf. Lanna 1992, para o caso trobriandês. 
Clastres reconhece que "certamente as esposas do chefe lhe darão filhas que serão mais tarde esposas potenciais para os jovens do grupo"; entretanto, rapidamente abandona esta possibilidade com o argumento de que "deve-se considerar que a reinserção das filhas no ciclo de trocas não compensa a poliginia do pai" (Clastres 2003a:56-7). Por "compensação", Clastres pensa aqui em equilíbrio perfeito. O argumento esvaziase, caso pensemos que esta compensação não é nunca do tipo "uma mulher dada implica outra mulher recebida", mas o privilégio da poliginia caracteriza-se justo quando o número de mulheres dadas é menor que o das recebidas; Clastres confunde compensação com igualdade e perfeita equivalência. O fato é que "a reinserção das filhas [do chefe] no ciclo de trocas" deve ser investigada; importaria saber se ela seria, como argumento aqui, sinal de reciprocidade assimétrica. Se Clastres, como LéviStrauss, trata como "privilégio" a poliginia de tantos chefes, ele tem ainda o mérito de salientar este dado etnográfico e indicar que ela está presente com incrível constância bem além do ambiente ameríndio. Por outro lado, importa tanto distinguirmos "compensação" de simetria e de equivalência como relacionar isto ao fato, sobejamente demonstrado por LéviStrauss, de que há mais nas trocas do que coisas trocadas, isto é, além das compensações dadas ou não, são subjetividades que se constroem. Importa também repetir que, ao contrário do proposto no cerne da teoria da "sociedade contra o Estado", trata-se aqui, se não exatamente de troca, de circulação de mulheres.

Ainda mais, o chefe não é excluído ou exteriorizado pelas mulheres que recebe ou bens e palavras que dá, não só porque também dá mulheres e recebe palavras e bens, como porque boa parte da circulação em um grupo qualquer (elementar, complexo, semicomplexo ou "sociedade a casas", não importa), dá-se em torno da figura do chefe. Esta figura, "a região do poder", não é assim exteriorizada pela da sociedade contra o Estado mas, ao contrário, representa, como veremos, uma continuidade entre sociedades sem e sociedades com poder coercitivo. Como Clastres intuíra - mas não exatamente da forma como ele intuíra - em qualquer grupo, independente do grau de centralização do poder, o chefe se faz chefe ou líder por sua posição privilegiada em relação à circulação; esta posição define um interior, mais ou menos centralizador, não um exterior, como quer Clastres. Em casos como o dos Araweté, onde não há um espaço público central que se defina pela figura de um chefe, nem donos de festas, xamãs ou outras posições (como a de cantores) fixas, onde nem xamãs nem guerreiros representam quaisquer imagens de um interior, há múltiplos líderes que se definem como iniciadores de atividades - 
tenotã mõ; estas sociedades não seriam apenas sem um centro, mas "pluricêntricas" (Viveiros de Castro 1992:101). Em todos os casos, naqueles onde há poliginia ou não, seja ela privilégio de chefe(s) ou não, a análise etnográfica dos casamentos revelaria circuitos (como os da sociedade kachin, por exemplo, descritos por E. Leach) regidos pelo princípio de reciprocidade, sempre assimétrica, desequilibrada. A poliginia do chefe, quando houvesse, seria apenas um momento desse(s) circuito(s) ${ }^{4}$.

Em resumo, aqui haveríamos de recorrer às etnografias. Há casos, como o dos Cinta-Larga, em que a poligamia é menos privilégio do chefe do que generalizada entre os homens e até mesmo entre as mulheres (Dal Poz 2004:155). Para os casos africanos, de Heusch (1987:45) aproxima os Nuer dos Shilluk como exemplos de "sociedades contra o Estado", interpretando o reth dos segundos como "fora do circuito das alianças: ele não dá suas filhas em casamento; estas têm relações sexuais com parentes próximos, mas devem permanecer estéreis". O rei é isolado do tecido do parentesco por não poder ter nem sobrinhos uterinos nem filhos de filhas, por não poder se encontrar em posição nem de tio nem de avô materno. Trata-se aqui de uma circulação diferenciada das filhas do reth, mas este não deixa de dá-las, ainda que não àqueles de quem recebeu esposas; como "possui um harém considerável", está assim dentro do jogo das alianças, mas este jogo não implica apenas um "circuito", como quer de Heusch, e sim vários, que precisariam ser melhor descritos neste como em tantos outros casos.

De certo modo, ao contrário do que pensa de Heusch, o reth Shilluk não é tão distinto de outros reis africanos mais sagrados; ele tem seu privilégio ampliado não só pelo seu direito ao harém como pelo fato de o círculo real Shilluk ter o privilégio do incesto ${ }^{5}$. Aqui há separação entre as funções guerreira e político-ritual, o reth não indo a combate, mas tendo o controle da natureza. Já o ambiente bantú se caracterizaria por diversos tipos de sacralidade do poder e organizações linhageiras, mas os Tetela do Zaire se aproximariam dos nilóticos, pois "o poder é definido pela estrutura familiar" e por noções como a de primogenitura (de Heusch 1987:46). Dádivas do rei alimentam "o circuito dos bens matrimoniais" (1987:47), mas ainda aqui, apesar de falar em primogênitos com direitos a pedaços de cada animal caçado e sendo concebidos como "mestres da terra", de Heusch não vê capacidade para tributar, pois o primogênito não tem nunca a função ritual dos adivinhadores/curadores. Ao contrário das realezas sagradas clássicas, aqui "a separação entre a esfera ritual e a política é completa, comparável, mutatis mutandis, àquela que opõe o chefe amazônico ao xamã" (1987:47). 
A realeza sagrada seria um outro tipo de chefatura; difere da "chefia amazônica" por incorporar funções rituais, mas também "não pode ser confundida com o Estado. Ela o precede, torna-o possível em [determinadas] circunstâncias históricas" (de Heusch 1987:56); implicaria uma "[...] revolução ideológica. O rei sagrado é estrangeiro ao ser da sociedade, de uma outra essência que a autoridade familiar, linhageira ou clânica" (de Heusch 1987:53); "a realeza sagrada é uma estrutura simbólica em ruptura com a ordem doméstica, familiar ou linhageira" (1987:51), e supostamente transgride a lei do parentesco "para se afirmar", caso da "realeza sagrada banta [que] instaura uma separação radical entre um poder político de essência ritual e o corpo social sobre o qual ele se exerce" (1987:53). Para de Heusch, o Estado africano se manifestaria em um terceiro tipo de chefatura; investida de função ritual, como a realeza sagrada, mas ainda mais exterior do que esta em relação ao parentesco, pela sua capacidade de tributar; é esta que inverte "o sentido da dívida" mesmo em casos em que não constatamos a existência de "aparelho de Estado", uma "coerção do imaginário" levaria ao pagamento de tributos (de Heusch 1987:48).

Entre os Pende, o tributo por excelência são crânios de inimigos ou de certos animais selvagens; neste caso, o chefe possui objetos sagrados que lhe garantem a propriedade nominal da terra e o direito de estabelecer tributos sobre a caça e a pesca (1987:50). Logo se vê que não se trata apenas de "revolução ideológica" na passagem a cada um destes três grandes grupos assinalados por de Heusch (no sentido restrito que ele dá ao termo "ideologia"); haveríamos de entender melhor o conteúdo sociológico das chefaturas antes de falarmos em diferenças de natureza. De Heusch critica sagazmente tanto a explicação funcionalista de Evans-Pritchard da realeza sagrada quanto o economicismo marxista e as explicações em termos do modo de produção doméstico; já meu argumento propõe que as explicações devam vir menos a partir de tipologias ou de transformações históricas do que de transformações lógicas e de uma retomada do modelo da reciprocidade.

Este modelo nos auxiliaria a descobrir futuramente transformações lógicas entre todos estes casos, assim como passar da análise de casamentos reais à tributação e ao consumo do rei e mesmo destes fatos sociológicos a princípios cosmológicos ${ }^{7}$. Voltamos à questão da unidirecionalidade. Para Clastres (2003a:56), o chefe só acumularia e redistribuiria os frutos de seu trabalho, não o de outrem. Mas além dos exemplos africanos, bastaria o do urigubu trobriandês para indicar as capacidades de um chefe primitivo para apropriar-se de trabalho alheio (no caso, de seus 
cunhados, fornecedores de suas esposas). Pensando em casos amazônicos e melanésios, o próprio Clastres fala que as esposas do chefe o sustentam nesta tarefa: ora, mas se o fazem - ao menos no caso trobriandês - o fazem enquanto representantes de grupos (matrilineares) comandados por seus irmãos, os cunhados do chefe. Este tem assim a capacidade de extorquir trabalho não apenas de figuras individuais (sejam cunhados ou esposas), mas de grupos aliados, grupos estes que, dependendo da sociedade, podem ser indivíduos, famílias, casas (no sentido lévistraussiano do termo) ou linhagens que se submetem em maior ou menor grau. Evidentemente, esta aliança pode ou não ser matrimonial e do ponto de vista da ideologia de qualquer sociedade, nem todo casamento de chefe é por definição hipergâmico. Meu argumento restringe-se aqui à esfera econômica; o chefe teria a possibilidade estrutural de ampla margem de manipulação de fluxos de bens: tudo o que ele desse seria valioso por definição. Ele teria o dever de ser mais o guardião da ideologia (nos sentidos tanto marxista como dumontiano do termo) do que da prática da generosidade.

Vale aqui notar outras influências marxistas presentes em Clastres. Ainda que fale em uma "recusa da economia" pela sociedade primitiva e em "recusa do trabalho (alienado) e, portanto, da desigualdade" (Fausto 1999:258), Clastres faz a política de certo modo substituir a economia como termo infra-estrutural (Clastres 2003a:220): a igualdade e a autonomia (ou, de modo mais psicológico, uma vontade de igualdade e de autonomia) ordenariam o econômico; este seria uma organização a posteriori, um epifenômeno derivado do político. O fulcro de seu raciocínio é o que ele mesmo denomina "seqüência ruptura da troca-exterioridade [do poder]impotência [do Estado]" (Clastres 2003a:60). Isto é, ainda que se valorizem ideais individualistas de independência e autonomia, semelhantes àqueles que Dumont (1977) mostrou estarem na base de textos clássicos de Marx, há uma inversão em relação a este: a vontade de igualdade determinaria "na base" a suposta "não-troca" entre chefe e "sociedade" e, ulteriormente, a produção primitiva como autônoma. Por outro lado, mantém-se certo funcionalismo de cunho marxista na relação entre esferas política e econômica, ainda que agora com o sinal trocado. Outra influência marxista notável - esta a meu ver positiva e presente também no Lévi-Strauss (1952) de Raça e história - é a coragem de não abrir mão de "uma teoria geral (a construir) da sociedade e da história" (Clastres 2003a:217), não mais a partir de uma filosofia da economia, mas sim da etnologia.

Mas ainda não nos livramos do fantasma da reciprocidade. Vimos que se Clastres afirma não haver troca entre chefe e grupos primitivos, não 
deixa de pensar esta relação a partir da dádiva: haveria "doação pura e simples [de mulheres] do grupo ao seu líder, doação sem contrapartida" (Clastres 2003a:57), assim como de bens e palavras do chefe ao grupo. Mas na perspectiva maussiana ${ }^{8}$, não somente não há nunca "doação pura e simples" (o free gift imaginado por Malinowski), como ao dar (bens e palavras) o chefe pode endividar o grupo, não apenas, nem necessariamente, submeter-se a ele. A meu ver, esta questão seria a da valoração diferencial tanto do que é trocado ou circulado em cada esfera quanto de cada circuito de dívidas - dádivas do chefe e para o chefe não deixariam de ser retribuídas, na medida mesmo em que fossem aceitas, ainda que esta retribuição pudesse ou não se materializar. Procurei em outro trabalho (Lanna 1995) mostrar como se pode generalizar em certas sociedades contemporâneas o paradigma dos brâmanes indianos, tal como descrito por Mauss (2003) no "Ensaio sobre a dádiva", em que bens e tributos dados a um centro são retribuídos por prestações imateriais (serviços religiosos, no caso brâmane); isto é, um movimento de bens materiais em um sentido é contrabalançado por outro movimento de oferendas não-materiais, valoradas como superiores, em sentido contrário.

Já na teoria de Clastres, fica implícita a generalização, errônea a meu ver, de certa superioridade a priori do recebedor de bens: dar mulheres seria um modo de aprisionamento do chefe primitivo, um preço que a sociedade estaria disposta a pagar para obrigá-lo a ser generoso, dar (ainda que, segundo Clastres, não à guisa de troca) bens e palavras, e abrir mão da coerção. Talvez houvesse aqui também influência marxista (e da juventude de ambos, Clastres e Marx), mas isto implica, o que é mais importante, negação da identificação pela piedade - idéia rousseauniana prolongada por Mauss e Lévi-Strauss - em nome de algum tipo de necessidade psicológica (inclusive, do ponto de vista da "sociedade", a da posse de bens). Assim, se Clastres compatibiliza seu modelo da política primitiva com o modelo de Sahlins (1972) da economia primitiva - um desejo de independência política coadunando-se a um ideal de autarcia econômica, "um ideal anticomercial" (Clastres 1982:184) - ele o faz a preço de uma redução de ambos, em última análise, a variáveis psicológicas (desejos, recusas e mesmo risco comercial).

Impõe-se a conclusão de que Clastres faz uma síntese original entre o princípio de reciprocidade - que, vimos em que sentido, ele não deixa de adotar - e concepções psicológicas da economia, do poder e da política típicas da filosofia política moderna anglo-saxã. Ainda que para ele a guerra não fosse "negatividade", mas "necessidade inerente à vida social" — primitiva, eu complementaria - Clastres estaria realmente "debruçado sobre 
premissas hobbesianas" (Cohn e Sztutman, 2003:A46). Ressurge aqui uma descontinuidade entre seus livros A sociedade contra o Estado e a Arqueologia da violência. No primeiro, como vimos, a troca é fundamento de uma ontologia primitiva, ou da "sociedade", mas no segundo este fundamento passa a ser a guerra, mantenedora (funcionalmente, eu complementaria) de um "ideal de liberdade e autonomia na recusa de uma esfera política separada, o Estado", ao mesmo tempo que "universalidade fenomênica na sociedade primitiva" (Cohn e Sztutman 2003:A46).

Em resumo, no modelo geral de Clastres, e no de $A$ sociedade contra o Estado em particular, a dádiva está presente de modo importante, assim como um determinado entendimento da troca. Apesar da noção de "troca aparente", o modelo da reciprocidade não deixa de se fazer presente na proposição de que o "privilégio" a mulheres do chefe seja contrabalançado por um privilégio da "sociedade" aos bens. A lógica do Clastres dos anos 1960 seria a de que, por estas relações não serem "igualitárias" (Clastres 2003a:53), deixariam de ser trocas. Já na Arqueologia da violência, como veremos, a guerra "responde a uma vontade preeminente de fragmentação e dispersão" e a aliança é reduzida não mais ao igualitário, mas à "tática" (Cohn e Sztutman, 2003:A46, grifo meu). Por isto afirmei acima que a guerra mantém "funcionalmente" o ideal da autonomia. Especialmente o artigo Arqueologia da violência (Clastres 1982) me parece, para parafrasear Florestan Fernandes, oferecer verdadeira teoria da "função social da guerra" na sociedade primitiva. Se para Clastres a guerra e a troca não estariam em relação de continuidade, por outro lado, naquele artigo, a aliança aparece "em favor da guerra", isto é, funcionalmente submetida a ela.

Clastres (1982:181) mesmo reconhece que em "Guerra e comércio", "a guerra se encontra claramente situada no campo das relações sociais". Ataca Lévi-Strauss por este supostamente opor guerra e dom, quando esta oposição está inscrita em alguns fatos etnográficos. Clastres não percebe que a proposição de continuidade entre guerra e dádiva é para Lévi-Strauss de ordem institucional e que por trás dela está, como nos relembra Fausto (1999), o princípio transcendental da reciprocidade. Mais ainda, não só devemos lembrar a tese de Lévi-Strauss de ser a guerra um modo de troca, mas também a de Mauss, no Ensaio sobre a dádiva, de que a troca é (ou melhor, pode ser) um modo de guerra.

Mas Clastres pretende demonstrar que "Lévi-Strauss não vê a guerra" (Clastres 1982:185). Em Arqueologia da violência, como indiquei, o fundamento da guerra é a vontade de indivisão; ao mesmo tempo, haveria "primazia" da guerra em relação à aliança e desta em relação à troca. 
Clastres afirma a descontinuidade — presente já em Lévi-Strauss (1949) — entre a troca instituindo a sociabilidade humana e a aliança enquanto instituição ou fato político e/ou matrimonial; mas sua análise recusa o nível transcendental do princípio de reciprocidade, adotando o sociológico, no qual as trocas matrimoniais seriam "um meio de concluir e reforçar a aliança política" (Clastres 1982:196, meu grifo salienta a razão prática desta passagem) ${ }^{9}$. Conclui que "existe troca porque existe aliança" (1982:195). Neste nível sociológico, realmente "o campo da troca matrimonial pode muito bem ser mais restrito do que o campo da aliança política", mas seu raciocínio vai além, acusando uma superioridade ou precedência lógica do campo político; o da troca matrimonial "não pode ultrapassá-lo: a aliança permite ao mesmo tempo a troca e a interrompe, ela é seu limite, a troca não vai além da aliança" (Clastres 1982:196). Conclui ainda que LéviStrauss não distinguiria estes "níveis" diferentes, apesar de concordar com ele em que "a sociedade humana se desenvolve no universo das regras e não no da necessidade, no mundo da instituição e não no do instinto" (Clastres 1982:195).

Mas sua análise não irá apenas situar-se no plano da regra e da instituição: Clastres vai imaginar regra e instituição primitivas contra a troca, "contra o Estado" e a favor da guerra; mais ainda: posteriormente, irá direcioná-las para o patamar da necessidade, da vontade e até mesmo de um certo instinto de liberdade. Seria neste sentido que a aliança de Clastres (que nada tem a ver com a de Lévi-Strauss) seria "limite" absoluto da troca.

O erro de Clastres seria reduzir a aliança à razão prática: dada sua inegável "inconstância" em ambiente amazônico, em relação a uma muito mais constante "solidariedade guerreira" (Clastres 1982:196), conclui apressadamente que ela "não seria um contrato" (Clastres 1982:194). Como por mágica, a troca que - Clastres reconhece, especialmente em A sociedade contra o Estado - "institui a sociedade" passa de infra-estrutural a subestrutural, ou de princípio transcendental a um nível mais restrito, "intracomunitário". Seria melhor tomar este aspecto instrumental como situado em um terceiro nível, fenomenológico, aquém dos outros dois mencionados aqui (o universal-transcendental e o institucional-sociológico). Como argumentei acima, a tarefa da antropologia política é estudar até que ponto "o campo da aliança política", longe de poder ser reduzido unicamente ao instrumental e às estratégias, também "constitui a sociedade". A meu ver, seria neste sentido que ela se distinguiria da chamada "ciência política". Seria ainda neste sentido que deveríamos valorizar as contribuições de Clastres, sua importante crítica à frágil "con- 
cepção instrumental do Estado" (Clastres 2003a:221). Entretanto, talvez sua intenção de criticar Lévi-Strauss e fugir de princípios transcendentais como o da reciprocidade o tenha conduzido, como a tantos outros, de volta ao funcionalismo.

Um dos problemas da Arqueologia da violência é assim retomar um pensamento em termos de meios e fins, posteriormente tão bem criticado por Sahlins (1976). Ao acusar Lévi-Strauss de "confundir fins e meios", ignora a importância da postura maussiana que se recusa a fundar a antropologia em um pensamento em termos de meios e fins. Isto é, parece-me condenável o esquecimento, de Clastres e tantos outros, de que o princípio de reciprocidade permite uma teoria da sociabilidade alternativa à liberal, que tudo reduz aos meios e aos fins, às escolhas e às estratégias (cf. Graeber 2001, especialmente o capítulo 6). Lévi-Strauss renova esta perspectiva maussiana justamente a partir da troca matrimonial e da sua teoria da aliança; não é que alianças não sejam "usadas" segundo interesses quaisquer, mas sim que, de todos os fatos sociais, os relativos à aliança e ao dom nos revelam caminhos privilegiados para pensarmos além das manipulações, em termos de linguagem, no sentido forte desta palavra.

Já Clastres reduz a troca de mulheres a um meio da aliança políticomilitar, esta entendida como submetida ao objetivo máximo das sociedades ameríndias, seu "ideal político", um desejo de independência. O paradigma é assim semelhante ao da razão prática liberal, apenas com as seguintes diferenças: se o homem, digamos, de um Milton Friedman maximiza utilidade, o homem primitivo de Clastres maximiza independência, e se autores liberais não revelam quaisquer escrúpulos em postular um homem universal (ainda que este ganhe caráter mais ou menos concreto em cada autor liberal $^{10}$ ), Clastres é mais cauteloso e reserva sua tese às "sociedades contra o Estado", mas sem negar a possibilidade deste ideal poder ser retomado. A questão reduz-se assim aos "propósitos" de cada sociedade.

Em resumo, o Clastres de Arqueologia da violência suprime o aspecto ontológico da noção de uma troca fundadora da sociedade, transformando-a em mera "necessidade", para usar termo seu, e submetendoa a uma variável psicológica. Como vimos, "tanto no plano da economia (ideal autárquico) quanto no da política (desejo de independência) a sociedade primitiva desenvolve constantemente uma estratégia destinada a reduzir o mais possível a necessidade de troca" (Clastres 1982:196). Novamente a "estratégia", por um lado, submete-se a um ideal e a um desejo e, por outro, submete a troca. Se em A sociedade contra o Estado a troca constitui o termo "sociedade", na Arqueologia da violência ela é ora "meio" da aliança política, ora "necessidade", mas deixa de ser a 
"essência do social" e passa a ser aquilo contra o que a sociedade, agora definida psicologicamente como ideal e desejo, se insurge; a troca passa a ser referência negativa do ser primitivo. Intuiria aqui Clastres que a troca produz desigualdades?

Seja lá como for, ele conclui com o seguinte truísmo: "a aliança funda a troca", truísmo psicologizante porque definido por ele mesmo como "interesse" (Clastres 1982:197). Mas o esforço não parece relevante, pois se para Lévi-Strauss "o ser social primitivo é o ser para a troca", não é verdade que, por isto, este tenha sido "levado a dizer que a sociedade primitiva é sociedade contra a guerra"(Clastres 1982:197). "Guerra e Comércio" apenas reproduz a indicação do "Ensaio sobre a dádiva" de que há momentos na história em que se coloca aos homens a alternativa entre a guerra e a troca, qualquer sociedade primitiva sendo para a troca, mas podendo ser também para a guerra. Assim, em certas circunstâncias históricas, uma sociedade pode ser "para a guerra", mas isto ocorre apenas na medida em que a guerra se institucionaliza como um modo de troca, caso das guerras indígenas amazônicas. Estas nos ensinam que a guerra não pode ser definida simplesmente como um modo de dizimação física do inimigo. Já guerras atuais, da África e da Europa Central, por exemplo, nos indicam que elas podem incluir ainda outro tipo de horrores, como o rapto de mulheres seguido de estupro e sua devolução. Mas não só a guerra é um modo de troca como também a troca é um modo de guerra; toda sociedade é simultaneamente assim para a guerra e para a troca.

Para o Clastres da década de 1970, a troca se submeteria não apenas funcional, mas também ontologicamente à guerra. Porém seu raciocínio se faz, como vimos, em boa medida, em termos de razão prática, chegando a pensar a troca como "efeito tático da guerra" (Clastres 1982:197-198). Evitase, dessa forma, uma reflexão mais aprofundada sobre a guerra ou a paz enquanto valores, assim como sobre a convivência entre elas. No caso de Lévi-Strauss, ao contrário daquele da razão prática, a guerra não é caos na medida em que esteja inscrita em uma estrutura, nem deve ser reduzida à tática ou a seus efeitos. É assim errôneo supor que sua noção de troca "nada tem a ver com a atividade sociopolítica que é a guerra" (Clastres 1982:198).

Fica claro que quando Clastres afirma que o estado de guerra é "estrutural" nas "sociedades primitivas", pensa em uma noção de estrutura diversa da de Lévi-Strauss. Sua "política interna" é então definida como um dogma, uma suposta "lei ancestral que não se pode alterar por nenhuma mudança", um "conservantismo", um perseverar-se enquanto "ser indiviso" que seria garantido pela guerra, "verdadeiro motor da vida social" (Clastres 1982:200). Esclarece-se outra diferença entre Clastres e Lévi-Strauss: este buscava, 
em "Guerra e comércio", justamente mostrar que não é verdade que, em todos os casos, "basta cessar a guerra e então cessará de bater o coração da sociedade primitiva", ainda que se conceda a possibilidade disto ocorrer em casos específicos. Demonstrar tal ponto, à luz dos conhecimentos etnográficos que acumulamos desde 1942, é tarefa ainda atual - bem realizada mais recentemente por Cohn \& Sztutman 2003.

Vimos que Clastres não deixa de considerar os aspectos sociológicos em torno da guerra primitiva. Mas acaba concluindo que a dispersão (morfológica) dos grupos locais seja "efeito" da guerra, pois esta "serve para manter cada comunidade em sua independência política", garantindo "a permanência da dispersão, da fragmentação, da atomização dos grupos" (grifo meu, novamente, pretende salientar a razão prática). Esta "lógica do centrífugo", do "múltiplo", seria "obstáculo sociológico" da "política interna", "centrípeta", "lógica da unificação" (Clastres 1982:201). Quando tal não ocorresse, haveria unificação pelo Estado e a sociedade deixaria de ser primitiva. Clastres define a sociedade primitiva assim, sociologicamente, como multiplicidade de comunidades indivisas que obedecem a uma lógica do centrífugo. A função social da guerra seria promover a dispersão contra a unificação, como uma inimiga do Estado; este, mais ou menos hobbesianamente, geraria a paz. É interessante notar que esta posição é justamente oposta à de Sahlins (n.d.), que associa o surgimento do Estado à intensificação da guerra e não da troca. Já uma perspectiva mais próxima da de Lévi-Strauss - creio eu, pensando em Raça e história - associaria o surgimento do Estado tanto à intensificação da guerra como da troca. Talvez pudéssemos ainda combinar as hipóteses de Clastres e Sahlins se nos fosse dado aqui relembrar os sentidos nos quais, em determinadas sociedades ameríndias, "o papel do xamã não difere essencialmente do papel do guerreiro" (Viveiros de Castro 2002:468). Importa-nos minimamente sugerir que tal aproximação pode ter relevância para uma hipótese lévi-straussiana para a origem do Estado (intensificação de guerra e troca). Este implicaria uma dupla transformação: em primeiro lugar, do xamã a sacerdote (cf. Viveiros de Castro 2002:471), através do profeta (Clastres) e, em segundo lugar, do guerreiro (Sahlins), este quiçá uma figura mais próxima do que temos imaginado em relação a um centro tributador.

Clastres fala não só em sociedade contra o Estado, mas também em profetas e karai contra a "ascenção dos chefes", liderando sociedades guaranis em migrações religiosas que seriam "a recusa da via em que a chefia engajava a sociedade, a recusa do poder político isolado, a recusa do Estado" (Clastres 2003a:232). Talvez a revolta dos karai fosse contra o surgimento de algum sistema de tributos desenvolvido a partir de intensifi- 
cação de trocas em torno da figura dos chefes. Clastres (2003a:234) reconhece que o karai é um "condutor de homens". Quanto a isto, a sugestão deste artigo é a de que não seria apenas "no discurso dos profetas" que teríamos o "germe do discurso do poder", que não apenas nele "se dissimula talvez a figura silenciosa do Déspota". Há de se inserirem outras figuras nesta equação, entre elas, como lembrava Lévi-Strauss em 1936, a do chefe Bororo.

De todo modo, a posição de Clastres parece criticável justamente por pensar guerra e Estado "em relação de exclusão", enquanto a posição de Sahlins tem o mérito de não excluir a imbricação entre guerra e Estado. Sem guerra, haveria para Clastres unificação e o fim da sociedade primitiva. Por outro lado, a perspectiva maussiana permite-nos ver melhor, em relação à de Sahlins, que a troca gera não só unificação, mas também diferenciação, que poderia ser tanto aquela referente à fragmentação das unidades sociais amazônicas quanto aquela inerente ao Estado.

Há de se notar a distância considerável entre o reconhecimento da universalidade da desigualdade que propus aqui e um entendimento mais aprofundado do fenômeno do Estado. Em que medida este se constitui a partir das trocas em torno do chefe? Quando estas poderiam ser consideradas tributos? Certamente futuras pesquisas sobre o englobamento da figura do Estado em sociedades primitivas seriam fundamentais, inclusive para tentarmos entender se haveria sentido em pensarmos em universalidade desta figura e até que ponto esta se representaria na da chefia. Entretanto, parece indiscutível reconhecermos ao menos algumas continuidades entre etnografias de sociedades "com" e aquelas supostamente "contra" o Estado. Este artigo tentou, ainda que não de uma perspectiva etnográfica, indicar alguns sentidos de tais continuidades. Sem dúvida, não seria aquele proposto por Sahlins (1985: nota 6). Ao mesmo tempo, há notável continuidade entre o simbolismo do cativo de guerra entre os astecas e os troféus de várias sociedades da América do Sul, como os "guerreiros do Chaco", por exemplo (cf., entre tantos outros, Fausto 1999:279). Há também continuidades evidentes, embora ainda não analisadas, entre aqueles casos africanos aos quais já nos referimos, que de Heusch prefere dividir em três tipos lógico-históricos.

Parece-me ainda que quaisquer estudos, referentes ou não ao político, não podem jamais dissociar "a fórmula sintética da troca" de eventuais "não reciprocidades de perspectivas", como faz Fausto (1999:263-264); ao contrário, aquela fórmula supõe a reciprocidade de perspectivas sempre diferentes (para um exemplo concreto disto, cf. a descrição do caso Cinta-Larga de Dal Poz 2004). Toda troca, em seu nível fenomenológico, factual, exige diferença, seja nos objetos, seja na posição dos trocadores, seja na temporalidade de cada movimento de dívida-dádiva que a alicerça; 
são estas diferenças ou desigualdades que fazem a passagem do fenomenológico ao transcendental, através do factual-institucional (cf. Lanna 1996). Fausto (1999) situa o que denomina "não reciprocidade de perspectivas" no nível fenomenológico: o desejo de um matador em não querer ser pago, supostamente contrário ao de um trocador pacífico. A meu ver, nem sempre na troca pacífica (se é que existe troca sem violência) o recebedor deseja receber de volta - e como disse, esta retribuição efetiva não me parece necessária para caracterizar reciprocidade. Do mesmo modo, há descrições de cativos tupinambás supostamente desejando sua própria morte, o que permitiria vinganças futuras. O fato é que estamos aqui no estágio dos desejos e não no das regras ou transcendências; nesta etapa, e aqui vale a razão prática, pode ser vantajoso dar algo sem receber de volta.

Mas há muito tempo Mauss já nos libertou desta discussão: importa a obrigatoriedade da dádiva mais que seu aspecto voluntário ou não. A dádiva parece assim ser o nexo entre a vontade e a obrigação, o particular e o universal, a diferença e a união, o fenômeno e a transcendência, a nãoreciprocidade e a reciprocidade de perspectivas. Falar em princípio de reciprocidade não significa necessariamente "encobrir a dimensão temporal" (Fausto 1999:264) nem obscurecer a fenomenologia da troca, mas sim adotar uma perspectiva fundamental, "do sistema total". Esta não é "a única legítima", mas pressupõe aquela dos trocadores, assim como toda etnografia e fenomenologia. Fausto critica lúcida e oportunamente Lizot por fazer uma "passagem sem mediações da guerra à troca" (Fausto 1999:263), mas a mesma crítica não pode jamais ser transferida a LéviStrauss, ainda que este não deixe de subsumir a guerra ao princípio de reciprocidade. Desejos e vontades - de bens, de morte (de si ou de outrem), de independência política ou econômica - são fatos empíricos, ou melhor, dados etnográficos, e não variáveis explicativas.

Clastres já foi criticado por supostamente repetir erros de evolucionistas que ele mesmo criticara e por postular uma dicotomia entre sociedades "com" e "sem" Estado, com o argumento de que substituiria o segundo termo pelo "contra o Estado". Tal me parece ser o caso: a sociedade primitiva não deixaria de ser por ele definida por uma falta e uma negativa - como vimos, a ausência de uma força como potência de sujeição e com capacidade de coerção - ainda que se trate de construção da "imagem positiva de uma sociedade que recusa o trabalho, a desigualdade 
e a sujeição" (Fausto 1999:259) e não da postulação de incapacidades (mentais, morais, sociais etc.) ao modo dos evolucionistas do século XIX, ou da pura negatividade que a guerra teria em Hobbes.

Vimos como há um sentido em que, modificado o argumento de Clastres, caberia dizer que a sociedade primitiva teria Estado, ainda que um Estado neutralizado, englobado. Já segundo Clastres, não apenas haveria na sociedade primitiva uma "chefia sem autoridade" (Clastres 2003a:47) — com prestígio, mas sem poder e capacidades coercitivas - mas nela o mal do "Estado" seria cortado pela raiz: não haveria continuidade entre o chefe indígena, que estaria a serviço da "sociedade", e o "Estado"; tratar-se-ia em cada caso de "dois tipos de sociedade absolutamente irredutíveis um ao outro" (Clastres 2003a:217). O "Estado" seria assim ardilosamente abortado pelos primitivos antes de nascer, exatamente na "região do poder". É evidente que uma dicotomia e uma descontinuidade se produzem: com e sem "Estado". Por outro lado, "sob a falta, as funções do Estado ausente seriam efetuadas pela estrutura social" (Lima e Goldman 2003:14). Mas neste caso, assim como na suposição da exterioridade do poder, "Estado" e poder não deixariam de estar presentes - nas figuras, respectivamente, de suas "funções" e região - ainda que, como eu dizia, sem se manifestarem coercitivamente. Caso contrário, como explicar a presença, "na região do poder", "das funções do Estado" aliada à suposta ausência destes termos?

Mas preferi não enfatizar a postulação de uma diferença essencial na tese da "sociedade contra o Estado". Clastres mesmo protestara, de modo algo contraditório em relação às suas teses centrais, contra os que vêem diferenças na "essência das sociedades", ao menos no nível econômico - com ou sem agricultura, por exemplo (Clastres 2003a:218). Evidentemente, o político e o poder não se reduzem ao Estado, como tantos já mostraram. Mas quando definimos o Estado pela dívida, como o fizemos aqui com Clastres, acabaremos pagando o custo de, para usar expressão de Lima e Goldman (2003:12), "recentrar a política no Estado". Resta-nos saber se não cabe falar em uma "região do poder" que englobe o Estado, voltar a tentar - como alguns, antes de Maquiavel definir a política ou entendê-la em seu sentido ontológico mais amplo, não mais a reduzindo à instrumentalidade de um jogo de forças, ao modo do pensamento liberal. Quem sabe, ao contrário do que pretende LéviStrauss (cf. nota 2), não seria enganoso nem pretensioso demais buscar, como fez Clastres na década de 1960, uma análise estrutural da política. Retomando dicotomias associadas por Viveiros de Castro (2002:464) àquela entre totemismo e sacrifício, talvez houvesse algo de categorial por trás da ação política, alguma forma por trás da força. 
Recebido em $1^{\circ}$. de março de 2004

Aprovado em $1^{\circ}$. de julho de 2005

Marcos Lanna é professor do Departamento de Antropologia e do Programa de Pós-Graduação em Antropologia Social da Universidade Federal do Paraná.

E-mail: <mlanna@ufpr.br>

\section{Notas}

* Uma versão inicial deste artigo foi apresentada no Grupo "Antropologia do Estado" da V Reunião de Antropologia do Mercosul, Florianópolis, em 30 de novembro de 2003, coordenado por Cimea Bevilaqua e Piero Leirner. Contribuíram discussões em torno da obra de P. Clastres travadas com Marcel Taminato e Paulo Roberto Homen de Góes, do Núcleo de Antropologia da Política e da Economia da UFPR. Evidentemente, os citados não podem ser responsabilizados por eventuais equívocos.

${ }^{1}$ Analisaremos a seguir o sentido que Clastres dá ao termo "sociedade".

${ }^{2}$ A pretensão de Lévi-Strauss de fazer análises do político foi gradualmente enfraquecida. Este enfraquecimento deve ser colocado no contexto de sua experiência no Brasil e envolvimento com a própria etnologia, tendo dado início a um processo de gradual distanciamento e relativização do fenômeno da política em geral. Mas logo após ter escrito sobre a chefia Nambikwara é que este processo se aprofunda e ganha outra importante motivação de cunho pessoal: Lévi-Strauss vê-se acometido por profunda desilusão consigo mesmo, pouco conhecida, talvez porque raramente mencionada por ele mesmo: "Acrescentarei ainda aqui algo que talvez seja essencial: eu fora pacifista antes da guerra e me enganara; e quando se é tão gravemente enganado, não há mais do que uma conclusão a tirar: é que não se tem queda para a política. Não se pensa mais em dar lições" (Lévi-Strauss 1987:1).

${ }^{3}$ Como vimos, poderíamos acomodar a tese de Clastres ao reconhecimento de que o próprio Estado estaria presente nas sociedades primitivas, ainda que sem necessariamente se manifestar ou se desenvolver institucionalmente; esta interpretação teria a dupla vantagem de excluir a dicotomia com/sem "Estado" e de nos permitir abandonar a noção de "uma necessidade inerente ao processo" que nos levaria a "procurar no nível da intencionalidade sociológica o lugar de elaboração do modelo" e a "postular uma racionalidade inerente a esta escolha" (Clastres 2003a:60, itálico do original); isto é, excluiríamos um finalismo que leva Clastres (quem diria?) a falar em escolha racional. Abordaremos com mais vagar, a seguir, a presença neste autor de um psicologismo funcionalista.

${ }^{4}$ Clastres afirma que, sendo o cargo hereditário (o que não ocorre em todo o contexto ameríndio que inspira suas reflexões), o privilégio da poliginia o seria também, e isto supos- 
tamente anularia possíveis efeitos da dádiva das irmãs do jovem chefe. Não vejo como, e a questão aqui nos remete necessariamente ao estudo etnográfico de caso particular, o que não posso apresentar aqui, assim como não pôde ser feito por Clastres, tanto pelo desenvolvimento dos estudos etnográficos em sua época, muito aquém do atual, como pela sua morte prematura. Outra (falsa) saída de Clastres para não enfrentar esta questão da retribuição das mulheres dada ao chefe é afirmar, de novo a partir de uma interpretação das idéias de LéviStrauss que me parece errônea — ainda que corrente na época em que Clastres escrevia — interpretação esta que privilegiava excessivamente a sincronia: "não é sobre o plano diacrônico das gerações sucessivas que se desenrola o plano do poder, mas sobre o plano sincrônico da estrutura do grupo" (Clastres 2003:57).

${ }^{5}$ De Heusch fala em "estabelecimento de contra-ordem familiar"; por exemplo, nas realezas sagradas de Ruanda e da Zwazilândia, "o rei, mestre da ordem social e cósmica, era autorizado também a ter relações sexuais com as irmãs de linhagem. Entre os Bugana, os Bunyoro e os Ankole a realeza aparece como uma tríade compreendendo o rei, sua mãe e uma meia-irmã", esta última sendo a esposa principal do soberano Bunyoro. Entre os matrilineares Kuba, o rei tem relações sexuais com uma irmã e se casa com uma sobrinha de seu próprio clã, ainda que perca sua filiação clânica ao ser entronizado (de Heusch 1987:49); aliás, este último rei incestuoso tem a capacidade de se transformar em leopardo para vingar seus inimigos (de Heusch 1987:51).

${ }^{6}$ Note-se aqui que, para de Heusch, as realezas divinas seriam casos intermediários entre as "sociedades contra o Estado" e o Estado propriamente dito. Já outros autores, como M. Sahlins (1985), confundem as duas primeiras figuras - erroneamente, se assumirmos a perspectiva do próprio Clastres. Ironicamente, em artigo dedicado à memória de Clastres, Sahlins (1985) interpreta como "contra o Estado" algumas sociedades, entre elas as polinésias, explicitamente classificadas pelo primeiro como "com Estado". Uma atenuante deste tipo de interpretação é que a identificação entre incesto real e atos naturais presente nas realezas divinas nos lembra realmente a exterioridade proposta por Clastres, "revelando na cultura selvagem uma identidade entre a [suposta] recusa da natureza e a [suposta] recusa do poder", e concluindo daí "que a cultura é de uma vez negação de uma e do outro na medida em que apreende o poder como ressurgência mesmo da natureza" (Richir 1987:63).

${ }^{7}$ É neste sentido que o próprio de Heusch cuida de valorizar a análise de J. C. Muller dos Rukuba da Nigéria central, na qual o regicídio, por exemplo, é tomado em sua dimensão social e cosmológica. Nesta sociedade, o chefe é eleito no clã dominante e morre simbolicamente antes de tomar posse bebendo a cerveja no crânio de um predecessor. Não haveria descontinuidade alguma entre a região do poder e a aldeia, que se identifica ao chefe, denominado por Muller "regulador econômico", distribuidor de excedentes e de palavras, "que maneja com facilidade e autoridade" (de Heusch 1987:54). Ainda que recuse o rótulo de evolucionista, de Heusch não explora o fato de que tais transformações são de ordem lógica antes de serem históricas, sendo tentado a ver esta chefatura como "estado primitivo da evolução da realeza sagrada" (de Heusch 1987:55). O chefe Rukuba trabalha com "seus administrados" na agricultura, sua casa é uma unidade de produção como as outras e sua produção não excede a dos outros agricultores; entretanto, ele tem "algumas vantagens econômicas" (de Heusch 1987:55), como receber o botim de guerra e 
pedaços de grandes animais caçados, que Muller não interpreta como tributos, ainda que reconheça que há "prestações que lhe são devidas", que ele é o "maior consumidor da aldeia" e que "os Rukuba dizem claramente que os grãos depositados no celeiro do chefe são dele em primeiro lugar" (citado por de Heusch 1987:56); ora, só assim ele poderia redistribuir excedentes "de maneira suntuária" (citado por de Heusch 1987:56).

${ }^{8}$ Assim como na teoria da gratidão de G. Simmel, que nisto antecede Mauss, como notou Dal Poz (2004:156;281-282).

${ }^{9}$ Clastres tem enorme mérito em sugerir que "o campo da troca matrimonial pode muito bem ser mais restrito do que o campo da aliança política", mas foi Viveiros de Castro (1993) quem posteriormente mostrou, para casos amazônicos em geral, que se trata não de relação funcional, mas hierárquica entre estruturas e práticas matrimoniais e princípios cosmológicos.

${ }^{10}$ Cf. Lanna (1994), para uma análise da manifestação do pensamento aqui rotulado como "liberal" em alguns antropólogos da chamada escola "britânica", como B. Malinowski, R. Firth e M. Douglas, entre outros.

\section{Referências bibliográficas}

ABENSOUR, Miguel. 1987. "Présentation". In: M. Abensour (org.), L'Esprit des lois sauvages. Pierre Clastres ou une nouvelle anthropologie politique. Paris: Seuil.pp.7-18. CLASTRES, Pierre. 1976. "Préface". In: M. Sahlins (org.), Age de pierre, age d'abondance. L'économie des sociétés primitives. Paris: Gallimard. pp.11-30. 1982 [1980]. A arqueologia da violência. São Paulo: Brasiliense. . 2003a [1974]. A sociedade contra o Estado. São Paulo: Cosac \& Naify. 2003b. "Entrevista com Pierre Clastres". In: A sociedade contra o Estado. São Paulo: Cosac \&Naify.pp.235-272.

COHN, Clarice e SZTUTMAN, Renato. 2003. "O visível e o invisível na guerra ameríndia". Sexta feira,7:A43-56.
DAL POZ, João. 2004. Dádivas e dívidas na Amazônia. Parentesco, economia e ritual nos Cinta-Larga. Tese de Doutorado, IFCH, UNICAMP.

De HEUSCH, Luc. 1987. "L'inversion de la dette (propos sur les royautés sacrées africaines)". In: M. Abensour (org.), L'Esprit des lois sauvages. Pierre Clastres ou une nouvelle anthropologie politique. Paris: Seuil. pp.41-59.

DUMONT, Louis. 1977. Homo aequalis I. Genèse etépanouissement del'ideologie économique. Paris: Gallimard.

FAUSTO, Carlos. 1999. "Da inimizade: forma e simbolismo da guerra indígena". In: A. Novaes (org.), A outra margem do Ocidente. São Paulo: Cia das Letras. pp.251-282. 
GRAEBER, David. 2001. Towards an anthropological theory of value: the false coin of our own dreams. New York: Palgrave.

LANNA, Marcos. 1992. "Repensando a troca trobriandesa". Revista de Antropologia, 35:129-148.

1994. "A categoria 'indivíduo' na obra de Malinowski". Revista Brasileira de Ciências Sociais, 24:122-132. 1995. A dívida divina. Troca e patronagem no Nordeste brasileiro. Campinas: Ed.Unicamp.

.1996. "Reciprocidade e hierarquia". Revista de Antropologia, 39(1):111-144.

LÉVI-STRAUSS, Claude. 1936. "Contribution à l'étude d'organisation sociale des indiens bororo". Journal de la Société des Américanistes, 28:269-304.

1943. "The social use of kinship terms among brazilian indians". American Anthropologist, 45:398-409. 1944. "Reciprocity and hierarchy". American Anthropologist, 46(2):266-268. 1949. Les structures élémentaires de la parenté. Paris: PUF. . 1952. Race and history. Paris: UNESCO.

1958. "Les organizations dualistes existent-elles?". In: Anthropologie structurale. Paris: Plon. pp. 147-180. 1976 [1942]. "Guerra e comércio entre os índios da América do Sul". In: E. Schaden (org.), Leituras de etnologia brasileira. São Paulo: Cia. Editora Nacional. pp.325-339.

.1987. "Sou um velho anarquista de direita". O Estado de São Paulo, Suplemento Cultura, 07 de março, pp.1-3. 1996 [1955]. Tristes trópicos. São Paulo: Cia das Letras.

LIMA, Tania Stolze e GOLDMAN, Marcio. 2003. "Prefácio". In: P. Clastres, A sociedade contra o Estado. São Paulo: Cosac \& Naify.pp.7-20.

MAUSS, Marcel. 2003 [1925]. “Ensaio sobre a dádiva. Forma e razão da troca nas sociedades arcaicas". In: Sociologia e antropologia. São Paulo: Cosac \& Naify. pp. 183-314.

RICHIR, Marc. 1987. "Quelques réflexions épistémologiques préliminaires sur le concept de sociétés contrel'État". In: M. Abensour (org.), L'Esprit des lois sauvages. Pierre Clastres ou une nouvelle anthropologie politique. Paris: Seuil. pp.61-71.

SAHLINS, Marshall. sem data. "War in the Fiji islands: the force of custom and the custom of Force". Manuscrito, Universidade de Chicago. Versão anterior à publicação, citada com permissão do autor. .1972. Stone age economics. Chicago: Aldine.

1976. Culture and practical reason. Chicago: The University of Chicago Press.

.1985. "The stranger-king or Dumézil among the Fijians". In: Islands of history. Chicago: The University of Chicago Press. pp.73-103.

2004. Esperando Foucault... ainda. São Paulo: Cosac \& Naify.

VIVEIROS DE CASTRO, Eduardo. 1992. From the enemy's point of view. Humanity and divinity in an Amazonian society. Chicago: The University of Chicago Press.

1993. "Alguns aspectos da afinidade no dravidianato amazônico". In: E. Viveiros de Castro e M. Carneiro da Cunha (orgs.), Amazônia: etnologia e história indígena. São Paulo: NHII - USP/ Fapesp. pp.150-210.

.2002. "Xamanismo e sacrifício". In: A inconstância da alma selvagem. São Paulo: Cosac \& Naify. 
Resumo

Este artigo avalia criticamente a contribuição de Pierre Clastres para o entendimento do poder, enfatizando sua noção de "sociedade contra o Estado". Mostra que a crítica de Clastres a Lévi-Strauss não exclui uma proposta particular de atualização daquilo que o primeiro denomina "troca recíproca" e indica que sua reflexão depende de uma concepção da reciprocidade que a confunde simultaneamente com simetria, equivalência e igualdade. Mostra ainda que a noção de "sociedade contra o Estado" não deixa de se fundamentar, em última análise, na proposição de um modo específico de relação de troca entre os termos "sociedade" e "Estado". Esta troca, cuja existência é negada por Clastres, é implícita e inconscientemente afirmada por ele.

Palavras-chave: Pierre Clastres, Estado, Reciprocidade, Claude Lévi-Strauss
Abstract

This article critically evaluates P. Clastres's contribution to our understanding of power, with particular emphasis on his notion of "society against the State". It demonstrates that Clastres's critique of Lévi-Strauss does not exclude a particular understanding of what he calls 'reciprocal exchange' and also indicates the extent to which the author's reflections are based on an understanding of the notion of reciprocity which mistakes it simultaneously for symmetry, equivalence and equality. The article likewise shows that the notion of "society against the State" depends on a specific kind of exchange relationship between 'society' and 'the State'. The existence of this exchange - explicitly denied by Clastres - is at once implicitly and unconsciously presumed by him.

Key words: Pierre Clastres, State, Reciprocity, Claude Lévi-Strauss 